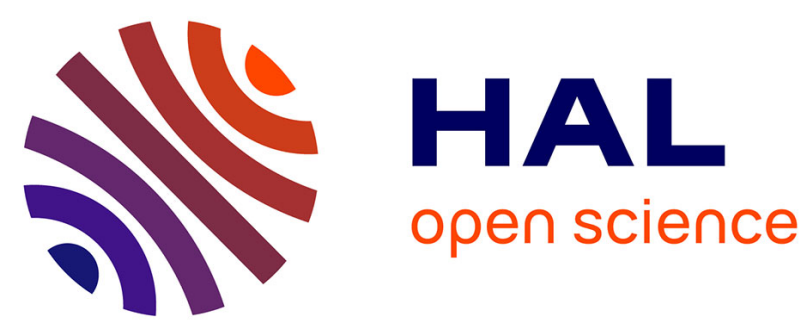

\title{
Adaptiveness to enhance the sustainability of farming systems. A review
}

Ika Darnhofer, Stephane Bellon, Benoît Dedieu, Rebecka Milestad

\section{To cite this version:}

Ika Darnhofer, Stephane Bellon, Benoît Dedieu, Rebecka Milestad. Adaptiveness to enhance the sustainability of farming systems. A review. Agronomy for Sustainable Development, 2010, 30 (3), pp.545-555. 10.1051/agro/2009053 . hal-00886511

\section{HAL Id: hal-00886511 https://hal.science/hal-00886511}

Submitted on 1 Jan 2010

HAL is a multi-disciplinary open access archive for the deposit and dissemination of scientific research documents, whether they are published or not. The documents may come from teaching and research institutions in France or abroad, or from public or private research centers.
L'archive ouverte pluridisciplinaire HAL, est destinée au dépôt et à la diffusion de documents scientifiques de niveau recherche, publiés ou non, émanant des établissements d'enseignement et de recherche français ou étrangers, des laboratoires publics ou privés.

$$
\text { Copyright }
$$




\title{
Review article
}

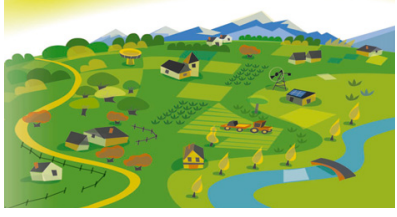

\section{Adaptiveness to enhance the sustainability of farming systems. A review}

\author{
Ika DARNHOFER $^{1 *}$, Stéphane BELlon ${ }^{2}$, Benoît DEDIEU $^{3}$, Rebecka MILESTAD $^{4}$ \\ ${ }^{1}$ Dept. of Economic and Social Sciences, Univ. of Natural Resources and Applied Life Sciences Vienna, Feistmantelstr. 4, 1180 Vienna, Austria \\ ${ }^{2}$ UR 0767 Ecodéveloppement, INRA, 84914 Avignon Cedex 9, France \\ ${ }^{3}$ UMR 1273 Metafort, INRA, Theix, 63122 Saint-Genès Champanelle, France \\ ${ }^{4}$ Dept. of Urban and Rural Studies, Swedish University of Agricultural Sciences, 75007 Uppsala, Sweden
}

(Accepted 2 November 2009)

\begin{abstract}
During the last decade the context in which farmers must manage their farm has changed rapidly, and often with little warning. Dramatic price swings for agricultural commodities, more stringent quality requirements, new environmental regulations, the debates surrounding genetically modified crops, extreme climatic events, the demand for energy crops, the revision of the Common Agricultural Policy and the consequences of the financial crisis all create uncertainty regarding future threats and potentials. During such turbulent times, a one-sided focus on efficient production is no longer enough. Farmers also need to be able to cope with unexpected events and to adapt to new developments. Based on a literature review, we identify three strategies that strengthen the adaptive capacity of a farm: learning through experimenting and monitoring its outcomes, ensuring a flexible farm organisation to increase the options for new activities by the farm family, and diversifying to spread risks and create buffers. Implementing these strategies enlarges the farmer's room to manoeuvre and allows identifying transition options. These options do not depend only on the farm itself, but also on the farmer's ability to mobilise external resources and to engage in collective action. Change is then no longer seen as a disturbance, but as a trigger for the reorganisation of resources, and for the renewal of the farm organisation and activities. Implementing these strategies comes at a cost, so that farmers need to tackle the inevitable trade-offs between efficiency and adaptability. However, unless farmers master this challenge they cannot ensure the sustainability of their farms.
\end{abstract}

adaptive farm management / adaptive capacity / evolutionary approach / complex adaptive systems

\section{Contents}

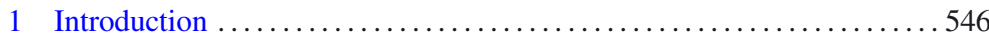

2 Three approaches in agronomy

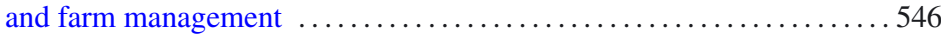

2.1 Improving crop and animal production based on an engineering

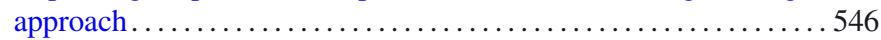

2.2 Applying systems thinking to farming .................. 547

2.3 An adaptive perspective in understanding farming systems . ....548

3 Strengthening the adaptive capacity of farming systems ............ 549

3.1 Learning through experimenting and monitoring ............. 549

3.2 Flexibility to increase response options ................. 550

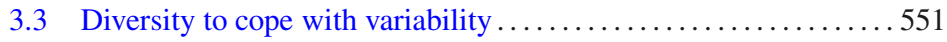

4 Conclusion .............................................. 552

*Corresponding author: ika.darnhofer@boku.ac.at 


\section{INTRODUCTION}

Farmers are faced with increasingly stringent environmental regulations, higher quality standards, detailed animal welfare demands and volatile markets, as well as uncertainty regarding the next reforms of the Common Agricultural Policy. Not only is the number of the demands made on farmers increasing, they are also becoming less predictable. The sources of uncertainty include the increasing frequency of extreme climatic events, the demand for energy crops and the debates surrounding genetically modified crops, as well as public health threats stemming from intensive animal production (e.g., BSE, avian influenza, swine influenza). Thus, although farmers have always had to cope with uncertainty, especially regarding weather patterns and prices, it seems that with globalisation the sources of uncertainty are becoming more diverse and the pace of change is increasing (Urry, 2005). This obviously has an impact on farmers' ability to plan ahead and to manage their farm so as to ensure farm continuity. The rapid pace and the often unforeseeable direction of change may increasingly require farmers to keep their farms flexible to be able to respond to new challenges as they arise.

However, the flexibility and adaptability of a farming system has seldom been the target of research on improving farming practices or designing technical innovations. Most of the developments have focused on increasing productivity, improving product quality, optimising production processes, reducing the environmental impact, minimising costs, or maximising profits. The recommendations derived from research were based on the implicit assumption that the general conditions on a farm and its socio-economic context would remain roughly the same. Offering farmers a stable context was also the goal of government policies which stabilised commodity markets and controlled imports. Although there were changes, these were introduced gradually and in a predictable way.

With liberalisation and globalisation leading to an increasing interconnectedness of markets and sectors, the assumptions of gradual and predictable change are increasingly challenged. The dynamics of the farming system and its context will thus need to receive more attention than they have in the past. To understand these dynamics better, insights derived from complex adaptive systems can be applied to farming systems. The complex adaptive systems view draws attention to the fact that change can be sudden and dramatic and that the links between components are important, rather than the components themselves (Manson, 2001). Systems are also adaptive, i.e. are in constant co-evolution with their environment (Rammel, 2003).

The aim of this paper is to succinctly review three approaches to farming and to indicate how the concepts from co-evolution and complex adaptive systems can be applied to increase our understanding of the sustainability of farming systems. To clarify how the adaptive approach differs from previous approaches, we first briefly review the theoretical concepts and assumptions underlying the engineering approach and the farming systems approach. We then elaborate on the implication of evolutionary and complexity thinking on the understanding of adaptive farming systems. We be- lieve that including the dynamic dimension of evolving farming systems can make an important contribution to understanding how farming systems can be more sustainable in a rapidly changing world.

\section{THREE APPROACHES IN AGRONOMY AND FARM MANAGEMENT}

We distinguish between three broad approaches that coexist in the farm management discourse: the engineering approach, the farming systems approach and the adaptive management approach. These three are loosely defined and we are aware that we cannot do justice to the wide variety of disciplinary refinements. However, using a broad-brush approach allows highlighting the differences in the underlying assumptions between schools of thought (see Tab. I). Although the three approaches were developed consecutively, they can all be found in current research, policy formulation and practice.

\subsection{Improving crop and animal production based on an engineering approach}

The attributes at the core of this approach are: efficiency, constancy and predictability. A problem such as low crop productivity or a threat from pests is identified, and a technological solution developed. Implementing the solution aims at achieving a predictable outcome such as a specific yield level. This approach to farm management is based on an engineering mindset. The goal is to 'design' a crop or animal production system, so as to turn a variable natural process into one that produces standardised commodities in a reliable, predictable and economically efficient way (e.g., Tsai et al., 1987). To achieve this stability agricultural pests are controlled through pesticides, nutrient competition is reduced through herbicides, natural, multi-species grassland is converted into monoculture, water supply for crops is regulated through irrigation or drainage, and field patterns are reorganised to reduce border effects and increase labour productivity (e.g., Fogel et al., 1974; Gotsch and Rieder, 1990). Recent developments, such as robotics and precision farming, aim at adjusting crop management steps to account for field variability by using technological means such as satellite navigation, sensors, computer models and information technology (e.g., Auernhammer, 2001; Bennis et al., 2008; Slaughter et al., 2008). The goal is to control processes, to reduce the range of natural variation of the farming system, and to stabilise the output of the farm so as to ensure an efficient and stable supply of goods and services (Grumbine, 1994; Holling and Meffe, 1996; Okey, 1996).

The solution to a problem is seen as being direct, i.e. there is a clear relation between cause and effect. It is seen as appropriate, i.e. the system has clearly defined boundaries and changes to the system have no effects outside these boundaries. And it is seen as feasible, i.e. relatively simple, without complex interrelationships. Generally, the focus is on an isolated issue, such as the nutrient supply for a crop (Tab. I). This 
Table I. Key characteristics of the three broad approaches to researching farms and farming systems.

\begin{tabular}{|c|c|c|c|}
\hline Characteristic & Engineering & Farming systems & Complex adaptive systems \\
\hline Underlying theory & Positivism, reductionism & $\begin{array}{l}\text { General systems theory, 'simple } \\
\text { systems', system dynamics }\end{array}$ & $\begin{array}{l}\text { Co-evolution, complex systems, } \\
\text { adaptive systems }\end{array}$ \\
\hline Systems view & $\begin{array}{l}\text { Mechanistic systems, } \\
\text { Newtonian science }\end{array}$ & $\begin{array}{l}\text { Systemic view: system is made } \\
\text { of parts that interact, focus on } \\
\text { the parts }\end{array}$ & $\begin{array}{l}\text { Hierarchically nested systems, } \\
\text { various temporal and spatial scales, } \\
\text { properties of complex adaptive } \\
\text { systems: emergence, hysteresis, } \\
\text { etc., } \\
\text { focus on interaction between parts }\end{array}$ \\
\hline Time & $\begin{array}{l}\text { Atemporal: time not taken } \\
\text { into consideration }\end{array}$ & $\begin{array}{l}\text { Atemporal but some linear } \\
\text { projection into the future; no } \\
\text { change in the dynamics of } \\
\text { a system }\end{array}$ & $\begin{array}{l}\text { Time is a key variable: 'history } \\
\text { matters', path dependency, } \\
\text { irreversibility }\end{array}$ \\
\hline Dynamics considered & $\begin{array}{l}\text { Static approach, steady-state, } \\
\text { equilibrium view }\end{array}$ & $\begin{array}{l}\text { Static approach, equilibrium } \\
\text { view, relationship between } \\
\text { elements does not change }\end{array}$ & $\begin{array}{l}\text { Perpetual disequilibrium, } \\
\text { non-linear dynamics, adaptability: } \\
\text { the dynamics change over time, } \\
\text { co-evolution }\end{array}$ \\
\hline Context & $\begin{array}{l}\text { Irrelevant ('one size fits all'), } \\
\text { allows for technological } \\
\text { blueprints }\end{array}$ & $\begin{array}{l}\text { Context matters: differences } \\
\text { between locations is important, } \\
\text { farmer perception needs to be } \\
\text { taken into account, focus on } \\
\text { agricultural sector }\end{array}$ & $\begin{array}{l}\text { Context is constantly changing, } \\
\text { change can be unexpected } \\
\text { in strength, timing and direction, } \\
\text { due to interactions need to include } \\
\text { all sectors, not just agriculture }\end{array}$ \\
\hline Inclusion of social sciences & $\begin{array}{l}\text { Mostly single discipline- } \\
\text { driven, some inclusion } \\
\text { of neoclassical economics }\end{array}$ & $\begin{array}{l}\text { Interdisciplinary: inclusion of } \\
\text { sociology to address farmer } \\
\text { perception, farmer participation, } \\
\text { economics include some } \\
\text { behavioural notions (e.g., agents } \\
\text { are boundedly rational), learning }\end{array}$ & $\begin{array}{l}\text { Interdisciplinary, inclusion of } \\
\text { insights from psychology such } \\
\text { as mental 'traps' and bias typical } \\
\text { to information processing } \\
\text { by humans, learning as an on-going } \\
\text { and interactive process }\end{array}$ \\
\hline
\end{tabular}

is based on the implicit assumption that there are no side effects on other parts of the farm or other spatial scales, and that the relations shown to be relevant over the short term are also the ones that will be relevant over the long term. The world is thus understood as stable, causal relationships are known, and there are no uncertainties. Farmers are seen as a homogeneous group and as business managers or entrepreneurs, so that farmer decision-making is assumed to comply with the model of economically rational agents (van den Bergh et al., 2000; Gowdy, 2007). Being rational, they will all reach a similar conclusion, which is expected to be comparable to the recommendation developed by scientists.

The normative and prescriptive technological solutions derived from this approach led to the strong increase in productivity in the 1970s and 1980s, both in crop and in animal production. This increase in productivity mainly took place in favourable production environments, i.e. good soils, reliable water supply, and a supportive economic and political framework such as ready access to cheap inputs, government-guaranteed output markets and stabilised prices. These favourable environments led themselves to the implementation of 'technological package solutions' (Norman, 2002).

The example of high yielding crop varieties can be used to illustrate the logic of the engineering approach. These are selected to comply with the DUS criteria (distinctiveness, unifor- mity, stability). These varieties are bred in centralised breeding facilities, with a few large companies claiming exclusive commercial rights to new plant varieties. The quality criteria are mostly breeder-driven and focus on efficiently producing a standardised quality, as required in industrial food processing. They achieve a high yield by being able to make best use of synthetic fertilisers, and tolerate herbicide application. Their performance is thus dependent on large-scale use of fossil fuelbased inputs and processes that help in limiting environmental variability (Tilman et al., 2002; Boody and DeVore, 2006; Wolfe et al., 2008).

\subsection{Applying systems thinking to farming}

The farming systems approach is generally characterised by an increased sensitivity by technical scientists to the complexity and variability of farmers' production environment, the recognition by economists of the limitations of the rational decision-making approach, the heterogeneity of farmers, and the recognition that it is not sufficient to optimise individual crops or animal production systems, as the farm needs to be understood as one system (Bawden, 1995; Hubert et al., 2000; Norman and Malton, 2000; Norman, 2002).

The importance of taking into consideration the farming context became increasingly evident as farmers, especially 
in less favoured areas, did not adopt the technological packages developed within an engineering approach. Technical scientists thus recognised that both the bio-physical and the socioeconomic components of a farm need to be considered, highlighting the usefulness of an interdisciplinary, systemic and gender-sensitive analysis (Hart and Pinchinat, 1982; Biggs, 1985; Jiggins and Röling, 1994; Dent et al., 1995) (see Tab. I).

There was increased awareness of the social nature of heterogeneity between farms and thus the importance of the farmer's perceptions and goals (e.g. Biggs, 1985; Lev and Campbell, 1987; Norman, 2002; Commandeur, 2006; Brodt et al., 2006; Odersteijn et al., 2006). Linked to these developments was the acceptance by economists that farmers' behaviour could not be understood only through maximisation of profit (Norton, 1976; Colin and Crawford, 2000), so that concepts such as satisficing behaviour (Simon, 1986) and bounded rationality (Kahneman, 2003) were included in the analysis. When making decisions, farmers and farm households also take into account issues such as long-term preferences, security, lifestyle and quality of life (Brossier et al., 1991; Gafsi and Brossier, 1997). Furthermore, farmers were often involved in the research process, e.g. to understand their norms, values and decisions rules better (Bellon et al., 1985; Collinson, 2000).

The farm is no longer seen as a mechanistic sum of (more or less) independent parts (Tab. I). Instead, a farm is viewed in its entirety, as a system (Osty, 1978; Béranger and Vissac, 1994; Bawden, 1995), as a change in one part of the farm often affects other aspects of the farm organisation. The farming systems approach thus focuses on the interaction between the parts of the system, and on the identification of improvements that were compatible with the whole farming system (Norman, 2002). For example, the livestock farming system approach proposed by animal scientists considers the farmer, the herd and the resources as one socio-technical system (Gibon et al., 1999). This implies that the interactions between its constitutive elements, as well as the self-regulating properties of biological systems, need to be taken into account (see Puillez et al., 2008).

The implications of this different understanding of agronomy and farming systems can be illustrated in how it shapes the selection of crop varieties. Instead of stabilising the production environment to achieve high yields, varieties are selected for being robust in a wide range of conditions, i.e. aim for yield stability across a wide range of temperature, nutrient and water conditions. Standardisation of quality is not seen as desirable, as farmers and consumers have different preferences, and traditional cuisine requires specific qualities found in landrace varieties (Sánchez et al., 2008). Desirable traits are not reduced to yield and qualities, but include systemwide considerations, such as balancing the nutrient needs in the whole crop rotation or the need for straw for animal housing (Wolfe et al., 2008). To take into account these preferences, breeding often takes place in a decentralised setting, with farmer participation (Sumberg et al., 2003; Bocci and Chable, 2008; Østergård et al., 2009).

\subsection{An adaptive perspective in understanding farming systems}

As the long-term environmental and social impact of intensive farming systems became increasingly apparent, the various issues related to ecological, economic and social sustainability came to the fore. This led to more attention given to longer-term effects, and raised the challenge to balance shortterm productivity increases with the long-term sustainability of farming systems. It also pointed out that the externalities of on-farm practices need more attention, and that the interaction between the farm and its context needs to be better understood. At a fundamental level, it highlighted the need to account for uncertainty as complex dynamics and interdependencies between sub-systems cannot be fully anticipated (EEA, 2001; Mayumi and Giampietro, 2001; Millenium Ecosystem Assessment, 2005; Campbell, 2008; IAASTD, 2009). With societal and farm dynamics being uncertain, there are bound to be unexpected developments that will require flexible adjustment (Tab. I).

There had been early calls for technologies to increase farmers' flexibility, to enable them to cope with changing economic environments (Long, 1984; Chambers, 1991, quoted in Norman, 2002; Lev and Campbell, 1987; Park and Seaton, 1996). Petit $(1978,1981)$ suggested a theory of adaptive behaviour in farm management, based on the observation that farmers interactively adjust both their objectives and their situations. This was illustrated by studying the patterns of change of farms over long time frames, offering empirical evidence that farm structure, activities and organisation can change substantially in response to on- and off-farm dynamics (Bourgeois and Krychowski, 1981; Levrouw et al., 2007; Cialdella et al., 2009).

Against the multi-dimensional background of socioeconomic, political and environmental dynamics, changes and adaptations increasingly seem to be essential elements in any approach towards a sustainable farming system. It is thus necessary to understand the (co-)evolution of a farming system with its environment and how this on-going change is reflected in the internal organisation of the farm and the farmer's goals. Given the uncertainties of future developments, previous concepts that guided research - such as stability, income maximisation, technical fine-tuning or biological optimisation - need to be balanced with concepts such as adaptability, resilience and flexibility.

The theories that might be used to inform an adaptive perspective of farm management are evolutionary theory and complexity theory. The term 'evolutionary' is used for theories that explain the driving forces requiring the adaptations of the system over time, and the mechanisms through which they operate. Evolutionary theories have mostly been developed in ecology. In the context of farms, these theories can help explain how farms generate and adapt to change, and how these processes are intertwined with what happens both at the level of individual farms and the higher level of markets and the farm's environment in general (see Rathe and Witt, 2001). In an evolutionary framework, continual development and change at the farm level is needed to maintain its 
'fitness' relative to the systems it is co-evolving with (Cournut and Dedieu, 2004). This on-going change implies that there is no stable state, no single optimal solution, no 'right' development path that can be defined a priori (Rammel, 2003). The evolutionary perspective requires a system to be adaptable, i.e. to be able to perform well according to unknown future conditions and goals that might change over time (Holling et al., 2002; Smit and Wandel, 2006; Rammel et al., 2007; van den Bergh, 2007; Fauvergue and Tentelier, 2008). The objective of management must include initiating and maintaining a diversity of alternative options so as to increase the chance of finding an adaptive response to unpredictable change (Beinhocker, 2006).

The theory of complex adaptive systems is another theoretical approach that focuses on understanding the implication of on-going change, and which emphasises the unpredictability of change (Ison et al., 1997; Levin, 1998; Manson, 2001; Holling, 2001). Complex adaptive systems are systems that involve many components and agents that interact simultaneously and adapt or learn as they interact (Holland, 2006). The theory of complex adaptive systems has been taken up by some researchers in economics and management sciences (e.g., Anderson, 1999; Meyer et al., 2005; Walsh et al., 2006; Teece, 2007), as well as in other social sciences (Stewart, 2001; Urry, 2005). This integration has proven fruitful as it allows one to understand how firms interact with their environment, how the past influences present behaviour, how the components interact (rather than focusing on the properties of the components), and how function is maintained, even though the components may be replaced (Cilliers, 2005; Trigeorgis, 2005). Within natural resource management, it has led to an approach called adaptive management (Lee, 1999; Westley, 2002; Jacobson et al., 2009). Given the similarities in the challenges faced by farmers and other society actors in the face of a rapidly changing context, it would seem that integrating insights from studies of complex adaptive systems and adaptive management can be useful to increase our understanding of the adaptability, resilience and persistence of farming systems.

\section{STRENGTHENING THE ADAPTIVE CAPACITY OF FARMING SYSTEMS}

Emphasising the adaptive capacity of farming systems is based on the premise that the key to coping with rapid and unforeseeable change is to strengthen the ability to adequately respond to change to sustain long-term survival. However, this needs to be balanced with the ability to take advantage of existing favourable conditions, i.e. to perform under current conditions. The challenge for farm management is thus to balance between long-term adaptability and short-term efficiency (Lev and Campbell, 1987; Giampietro, 1997). Studies of natural resource management indicate that the characteristics allowing a social-ecological system to strengthen its adaptive capacity include the ability of the manager to learn, the flexibility of a system and its diversity.

\subsection{Learning through experimenting and monitoring}

The existence of uncertainty and surprise as well as their unpredictable nature (Funtowicz and Ravetz, 1993; Folke et al., 2003) requires a continuous learning process that attunes to new information by reformulating hypotheses and models, and understanding activity implementation as experiments (Westley, 2002; Hagmann and Chuma, 2002). For example, there could be different interpretations as to the cause of an animal disease such as calf scour, leading to different assumptions on how to best tackle the disease. Whereas one farmer might rely exclusively on the veterinarian to treat the disease when it appears, another will experiment with different preventive measures and adapt processes on her farm (Magne and Cerf, 2009). Indeed, farmers' choices are constrained by their personality, preferences and competences, but also by external structures such as the social norms, technologies and the natural environment. Acknowledging that there are different valid solutions for each problem allows one to see that a farmer might find some solutions more useful than others depending, e.g., on her priorities, farming style and context. Learning is thus not seen as an objective attempt to understand the "world out there', but as based on a relational understanding of reality: learning allows for a new perspective of challenges and for perceiving new possibilities.

To increase the number of learning opportunities and to structure them, it is useful to experiment and monitor the outcomes. Experimentation allows a better understanding of current system dynamics; for example, the influence of buffer strips on the insect population and reduction of pest incidence. It also allows widening the repertoire of options in case of changes in the context. For example, a farmer might experiment with mechanical weed suppression to reduce herbicide use or experiment with on-farm processing to see whether it would be compatible with work flow and meet consumer demand (Sumberg et al., 2003). In this framework, quantitative information is often less important than understanding the 'rules of the game' and how these rules change. Unexpected outcomes, active experiments to test hypotheses and monitoring through feedback systems allow farmers to learn about local agroecosystems, about the dynamics of social institutions, and about the potential and limits of various technologies and processes, and therefore actively adapt their farm management.

This approach stresses the role of creativity and imagination, and recognises the crucial role of the farmer for the development of a farm over time. Indeed, what a farm can produce with given resources hinges critically on the conceptions, capabilities and projects of the farmer (Rathe and Witt, 2001; Teece, 2007; Gueringer et al., 2009). The farm is thus no longer seen as a device to exploit economies of scale and scope as a response to technological progress. Rather, farms are interpreted as learning systems whose survival and growth strongly depends on the successful generation and integration of new knowledge.

Learning is not limited to experiments a farmer undertakes to understand a specific aspect of his farming system better. Much learning takes place through discussions with 
others, and when expanding on local and traditional knowledge (Berkes and Folke, 2002; Sumberg et al., 2003). For example, by building on the experiential knowledge of older farmers, who know which pastures remain productive even during drought, a farmer can broaden his options for action when faced with a similar crisis. But monitoring need not be done on an individual basis. It can involve a range of local stakeholders (Couix and Hubert, 2000). A farm monitoring and study group can provide a collective learning environment, in which ideas are shared and the results of experimentation with delayed lambing, flexible bull finishing and cross-breeding are analysed in detail, thereby confirming or disproving ideas for new practices (Seath and Webby, 2000).

Learning also benefits from combining different types of knowledge, e.g. experiential and experimental knowledge (Scoones and Thompson, 1994), from expanding from knowledge of structure to knowledge of function, from understanding about the dynamics of complex systems, and from understanding the complementarities of different knowledge systems such as scientific and traditional knowledge (Folke et al., 2003). Indeed, local knowledge systems can be based on a different conceptualisation of the world compared to sciencebased farm management (EEA, 2001; Olsson and Folke, 2001; Macé et al., 2007). It is thus important not to dilute, homogenise or diminish the diversity of knowledge systems, but to nurture diversity (Folke et al., 2003). Farmers' learning can benefit from comparing diverse information sources and perceptions, for example, by discussing new ideas with people belonging to different social groups. Off-farm employment or engagement in community organisations (e.g., church, sports club, hunters, fire brigade) allows access to various information sources, different world views, and different understandings of societal trends, consumer preferences or upcoming changes in agricultural policy. By discussing new ideas with a variety of people and reflecting on their views, a farmer may learn new ways to interprete and explain phenomena and thus discover new options to act (Ison et al., 2000; Odersteijn et al., 2006).

\subsection{Flexibility to increase response options}

In management sciences, the concept of flexibility is seen as a means to face uncertainty and thus also defined in relation to adaptive capacity (Reix, 1979). Generally, there is a distinction between operational and strategic flexibility. Operational flexibility refers to the ability of a system to implement changes in the short term when facing surprises. Strategic flexibility refers to long-term choices and to the capacity to change the structure, the resources, and the competences of the farm in anticipation of, or to react to, changes in the environment. For example, farm households not only need to ensure that they can flexibly change their daily or weekly work schedule to respond to changing weather patterns (operational flexibility), they also need to be able to develop new on- or off-farm enterprises (strategic flexibility).

Tarondeau (1999) further identified three sources of flexibility in production systems: the products, i.e., their diver- sity and exchangeability; the processes, i.e. the organisation of work and of the technical systems that allows for several processes; and the input specificity, i.e. whether different sources of inputs can be combined or substituted rather than depending on one specific input. This concept has been used to analyse the adaptive capacity of farming systems (Bellon et al., 2004; Lopez-Ridaura et al., 2005). As the available work force is often limited on farms, work organisation is of particular importance: what tasks need to be done, who can perform the task, is it possible to hire skilled workers, can work flows be adapted to react flexibly, e.g. to changing weather (for a review see Madelrieux and Dedieu, 2008).

For example, livestock farms in pastoral systems may be specialised and have only dairy cows, or they may keep a flexible mix of dairy cows, suckling cows, heifers and oxen. Work organisation and processes may be based on regular routines and a clear differentiation of tasks to be performed by each worker, or they may be flexible and make room for contingencies. Regarding inputs, a study by Gueringer et al. (2009) shows the possibility of coping with changing fodder availability through spatial management of grassland fields and flexible fodder purchase. The farmers differed in their combination of harvesting technique, i.e. grazing, harvest as hay or harvest as silage to be stocked as wrapped bales, depending on various factors such as grass regrowth, labour availability, quality schemes (hay-only milk), spatial location of the fields (size of field and distance between individual fields), and available storage options. Farmers may also increase their flexibility by adapting stocking density and herd composition (dairy cows, suckling cows, calves) to available fodder and labour, as well as market demand (Lemery et al., 2006).

This illustrates the complexity with which farmers are confronted on a daily basis, in an attempt to remain flexible while maintaining the overall coherence of their farm. Farmers have to maintain various sources of flexibility over the short term, e.g. fodder sources over one season, and over the medium term, e.g. type and quality of milk and meat produced, as well as in the long term. As a study of change patterns on 14 farms during a 50-year period has shown, farms implement a wide set of adaptability options by flexibly organising the workload of family members, changing the structure of animal production and using off-farm employment, as well as various forms of cooperation with neighbouring farms (Cialdella et al., 2009).

Indeed, flexibility does not depend only on processes internal to the farm but also on its capacity to enrol external resources. Chia (2008) has called this ability 'relational flexibility', i.e. the ability of a farm to mobilise external resources through collective action. This might take the form of processing or marketing cooperatives to promote a specific quality label, the purchase of machinery by several farmers, or establishing a company to run a common biogas plant. On a smaller scale it also includes mutual help and exchanges. For example, the flexibility of the management of grassland fields can be enhanced, if the farmer not only considers her own fields, but is able to arrange with a neighbouring farm for, e.g., a seasonal exchange of plots or labour (Gueringer et al., 2009). 
Emphasising flexibility thus highlights that the processes on a farm, its work organisation and the products and services marketed by a farm at any given time merely represent one of several ways in which it could be using its resources. Indeed, the 'productive opportunities' of the farm, even with an unchanged set of resources, are not objectively given. A farm is essentially a pool of resources that can be used and combined in different ways (Penrose, 1997). This means that for a farm, it matters how the components are linked and the way in which the resources are used, not just the resources themselves. What matters is how flexible the arrangements are, and whether or not the selected technological paths enable reversibility. To ensure flexible rearrangement, modularity, i.e. the ability to combine subroutines, actions or resources in different ways plays an important role. Modularity allows farmers to respond to change by combining a set of available resources. The novel combination of available building blocks is often more flexible than trying to anticipate each possible situation with a distinct strategy or resource (Holland, 2006).

\subsection{Diversity to cope with variability}

Clearly, flexibility is in part linked to diversity, i.e. the ongoing development and management of a portfolio of alternative capabilities, opportunities and relationships (Smit and Trigeorgis, 2006). Managing complex systems and uncertain future developments implies spreading risks and creating buffers, i.e. not putting 'all eggs in one basket'. The evolutionary potential of a farm, its ability to initiate new development trajectories, builds on the diversity of co-existing activities, its repertoire of alternative options and innovative activities (Rammel and van den Bergh, 2003). This diversity has been shown to play an important role in the reorganisation and renewal process following disturbance (Folke et al., 2003) as it enlarges a farmer's room to manoeuvre.

One way to approach diversity is at the whole-farm level. Here, activities of the members of the farm household can be diversified, which includes both on- and off-farm activities (Bryden et al., 1992; Lemery et al., 2005; Cialdella et al., 2009). A diversity of resources available on the farm, such as family labour, knowledge, networks, arable land, grassland and buildings can be invested in a range of projects. These projects will in part depend on the diversity of opportunities offered by the context, such as proximity of the farm to a city offering employment opportunities or a demand for fresh local products, or a village dairy manufacturing quality labelled cheese or the city council outsourcing services such as composting, snow ploughing or roadside maintenance to farmers. Thus, even if the focus is on the farm, the context needs to be taken into account, as it shapes the diversity of options available. Of course, this diversity can be enhanced by the farmers, especially if they engage in collective action, e.g. such as establishing a cooperative to process and package their produce (Chia, 2008; Cialdella et al., 2009). Also, diversity is not objectively given, but depends on the creativity of farmers to be innovative and creative. Indeed, different perceptions (Magne and Cerf, 2009) and interpretations of societal trends can make the farm and community more robust.

Unfortunately, strategies to build diversity are not yet well understood (Penrose, 1997), as most research efforts have focused on efficiency and specialisation. More research is needed to understand diversification and pluriactivity, the coordination and interaction between the activities leading, e.g., to challenges in work organisation (Fiorelli et al., 2007; Madelrieux and Dedieu, 2008). Indeed, farmers increasingly complain of too high work pressure and lack of work-free time (weekends, vacations). The challenge in building diversity is thus not only to coordinate labour peaks and to ensure the flexibility necessary to accommodate unpredictable events, but also to ensure quality of life through a satisfactory worklife balance for all members of the farm family.

Another way to approach diversity is at the technical system level. Here, the focus is on the role that diversified resources, production processes and type of products play to secure the system and to allow its evolution. For instance, a study has shown that creating and maintaining a diversity of land resources can play a key role in the management of a dairy farm, especially to reduce the sensitivity of milk production to climatic variations (Andrieu et al., 2008). Similarly, a system that allows for a diversity in crops (Østergård et al., 2009) or herd management (e.g., composition, age, uses, etc.) seems to be more resistant to periodic forage shortages, especially when considered at the herd level and over the long term (Tichit et al., 2004).

Diversity can also be approached at the functional level (Elmqvist et al., 2003; Walker et al., 2006). The focus is then not on diversity to allow various responses to change, but on ensuring that a function on the farm, such as ensuring adequate nutrient supply for crops, can be supplied by different processes, such as synthetic fertilisers, compost or adequate crop rotations. At the farm level, functional diversity means that the farm can perform several functions, i.e. is multifunctional, thus addressing a range of societal demands (Wilson, 2008; OECD, 2009). This approach allows one to avoid the sectoral approach to farming, which tends to focus on food, fibre and fuel production, and widen the perspective to the provision of public goods and services such as ecosystem services, cultural landscape or climate change mitigation.

Maintaining diversity in the current activities as well as maintaining diversity of future options implies that not all resources are used efficiently at any one point in time. In other words, there will be apparently redundant resources that are maintained 'in case' something happens, when they might be useful. Keeping unused buildings, machinery or land involves costs and thus reduces efficiency in the short term. However, diversity and redundancy are an insurance against uncertainty and surprise, and need to be actively nurtured to allow for reorganisation and renewal. A farm will thus have to pursue parallel strategies by exploiting today's capabilities and at the same time exploring new projects. In stable periods, the focus is likely to be on exploiting current strengths while during turbulent periods it will be more important to assess which of the projects are likely to meet the demands of the new context. For example, whereas until the mid-1990s livestock farmers were 
able to focus on the production of standardised quality, since the BSE crisis in the late 1990s the quality specifications, documentation and traceability requirements have increased dramatically. A farmer that had a range of marketing channels and had experience with quality production thus adapted more easily to the changes than a farmer that had focused exclusively on mass production of standard quality (Chia, 2008). Diversity thus implies a dynamic process involving multiple parallel strategies, which allow one to adjust or switch between various alternative paths as the strategy unfolds.

Putting diversity to use implies that decision rules need to change over time, to adapt to changes in requirements, preferences or context. Farmers are thus faced with the challenge of deciding which rules to change when, and how to change them. Holland (2006) has called them the 'credit assignment problem' and the 'rule discovery problem'. The first problem arises because overt information about performance and efficiency is often irregular and partial. Indeed, why a strategy was successful is hard to establish, since the strategy is the result of a long line of choices extending over space and time. Holland (2006) uses the metaphor of a game of chess, where a winning player has little information about which moves along the way were critical to success. The rule discovery problem arises when it becomes obvious that some of the farmer's decision rules are ineffective. Rules serve as tentative hypotheses about the farmer's environment. As that environment evolves, some rules will be progressively disconfirmed. The question then is: how to select a new, more adequate decision rule. As these challenges show, maintaining an appropriate level of diversity, and making use of that diversity are not trivial management issues.

\section{CONCLUSION}

Farmers have always had to cope with a certain level of change and unpredictability and thus needed to be flexible and adapt to new circumstances. However, with globalisation, sectors and countries are increasingly interconnected, leading to spill-over effects, so that change is different both in speed and variety. Adaptability is no longer just one factor enhancing competitiveness on the market, it has become a key aspect of farm survival.

Enhancing adaptability goes against the recommendations derived from an engineering approach to farm management, which tend to create simplified, specialised farms. Their impoverished diversity limits their capacity to adapt to societal change. Coping with ubiquitous change also demands broadening the perspective found in farming systems, to integrate the options built through collaborative actions by several stakeholders, as well as emphasising dynamics and adaptability.

Understanding the ability of farms to be adaptive raises the challenge to identify and develop methods to capture the dynamics of a system, and analyse which characteristics strengthen or threaten the ability of farms to adapt. Participatory methods are a promising avenue, as most disciplinary scientific models cannot capture the complexity of relationships or their dynamics, whereas farmers juggle them on a daily basis. Thus, researchers face the dual challenge of developing adequate theories and methods to understand the dynamics of co-evolution, as well as ensuring that their recommendations are relevant to real-world decision-making.

Learning to live with change and uncertainty requires a fundamental conceptual shift, from assuming that the world is in a steady state to recognising that unexpected change is the rule. Farms and farming systems undergo constant reorganisation, with phases of more or less fundamental modifications. Through our literature review we have shown that learning, flexibility and diversity, in their various forms, play a key role in the strategies of farm households to cope with change. The goal of these strategies is both to recognise the opportunities offered by change and to implement them by initiating transition processes. As learning, flexibility and diversity require resources, they are costly. Farmers thus face the inevitable trade-offs between efficiency and adaptability. Ensuring the economic, social and ecological sustainability of farms is a dynamic and complex adaptation process, in which strategies and contexts co-evolve.

Acknowledgements: We would like to extend our gratitude to the two anonymous referees and to the editor for their constructive criticism and helpful suggestions, allowing us to improve on the paper's earlier version. We also thank the participants at the IFSA 2008 conference in Clermont Ferrand for providing so many case studies illustrating the adaptability of farms.

\section{REFERENCES}

Anderson P. (1999) Complexity theory and organization science, Organization Sci. 10, 216-232.

Andrieu N., Coléno F., Duru M. (2008) L'organisation du système fourrager source de flexibilité face aux variations climatiques, in: Dedieu B., Chia E., Leclerc B., Moulin Ch., Tichit M. (Eds.), L'élevage en mouvement. Flexibilité et adaptation des exploitations d'herbivores, Ed. Quae, Paris, pp. 97-112.

Auernhammer H. (2001) Percision farming - The environmental challenge, Comput. Electron. Agric. 30, 31-43.

Bawden R. (1995) On the systems dimension in Farming Systems Research, J. Farming Systems Research-Extension 5, 1-18.

Beinhocker E.D. (2006) The origin of wealth. Evolution, complexity and the radical remaking of economics, Harvard Business School Press, Boston.

Bellon S., Guérin G., Léger F. (2004) Anticiper les aléas climatiques en programmant des sécurités, in: Duboeuf J.P. (Ed.), Evolutions of sheep and goat production systems: Future of extensive systems and changes in society, Options méditerranéennes, Série A, ${ }^{\circ}$ 61, Ciheam/ FAO/ ICZS/ Cirval, pp. 137-146.

Bellon S., Mondain-Monval J.F., Pillot D. (1985) Recherchedéveloppement et farming system research: à la quête de l'opérationnalité, Proceedings of the colloquium on 'Caribbean farming systems and alternatives for development', held 9-11 May 1985 in Martinique, Univ. Antilles-Guyane, DAC, pp. 467-486.

Bennis N., Duplaix J., Enéa G., Haloua M., Youlal H. (2008) Greenhouse climate modelling and robust control, Comput. Electron. Agr. 61, 96-107.

Béranger C., Vissac B. (1994) A holistic approach to livestock farming systems: theoretical and methodological aspects, in: Gibon A., Flamant J.C. (Eds.), The study of livestock farming systems in a research and development framework, EAAP Publ., 63, pp. 5-17. 
Berkes F., Folke C. (2002) Back to the future: Ecosystem dynamics and local knowledge, in: Gunderson L.H., Holling C.S. (Eds.), Panarchy, Understanding Transformations in Human and Natural Systems, Island Press, Washington DC, pp. 121-146.

Biggs S.D. (1985) A farming systems approach: Some unanswered questions, Agr. Admin. 18, 1-12.

Bocci R., Chable V. (2008) Peasant seeds in Europe: Stakes and prospects, Cah. Agric. 17, 216-221.

Boody G., DeVore B. (2006) Redesigning agriculture, BioScience 56, 839-845.

Bourgeois A., Krychowski T. (1981) L'adaptabilité des exploitations laitières: essai d'appréciation de certaines de ses composantes, à partir de douze cas du Maine-et-Loire, Fourrages 88, 3-38.

Brodt S., Klonsky K., Tourte L. (2006) Farmer goals and management styles: Implications for advancing biologically based agriculture, Agr. Syst. 89, 90-105.

Brossier J., Chia E., Marschal E., Petit M. (1991) Gestion de l'exploitation agricole familiale et pratiques des agriculteurs : Vers une nouvelle théorie de la gestion, Revue Canadienne d'Économie Rurale 39, 119-135.

Bryden J.M., Bell C., Gilliatt J., Hawkins E., MacKinnon N. (1992) Farm household adjustment in Western Europe 1987-1991, Final report on the research programme on farm structures and pluriactivity, Luxembourg: ECSC-EEC-EAEC.

Campbell A. (2008) Paddock to plate: Food, farming and Victoria's progress to sustainability, The Future Food and Farm Project Background Paper, Australian Conservation Foundation, Melbourne.

Chambers R. (1991) Complexity, diversity and competence, Toward sustainable livelihood from farming systems in the 21 st century, J. Asian Farming Systems Association 1, 79-89.

Chia E. (2008) La flexibilité relationnelle : rôle des réseaux, groupements et associations d'éleveurs, in: Dedieu B., Chia E., Leclerc B., Moulin Ch., Tichit M. (Eds.), L'élevage en mouvement, Flexibilité et adaptation des exploitations d'herbivores, Ed. Quae, Paris, pp. 137-144.

Cialdella N., Dobremez L., Madelrieux S. (2009) Livestock farming systems in urban mountain regions. Differentiated paths to remain in time, Outlook Agr. 38, 127-135.

Colin J., Crawford E. (2000) Economic perspectives in agricultural systems analysis, Rev. Agric. Econ. 22, 192-216.

Cilliers P. (2005) Complexity, deconstruction and relativism, Theory, Culture and Society 22, 255-267.

Collinson M. (2000) A history of farming systems research, Wallingford: CABI Publishing.

Commandeur M.A. (2006) Diversity of pig farming styles: understanding how it is structured, NJAS-Wageningen J. Life Sci. 54, 111-127.

Couix N., Hubert B. (2000) Promoting collective learning in a landuse management project: Thirteen years' experience in researchertechnician partnership in the Cévennes, France, in: Cerf M., Gibbon D., Hubert B., Ison R., Jiggins J., Paine M., Proost J., Röling N. (Eds.), Cow up a tree, Learning for change in agriculture - Case studies from industrialised countries, Paris: INRA, pp. 121-140.

Cournut S., Dedieu B. (2004) A discrete event simulation of flock dynamics: A management application to three lambings in two years, Anim. Res. 53, 383-403.

Dent J.B., Edwards-Jones G., McGregor M.J. (1995) Simulation of ecological, social and economic factors in agricultural systems, Agr. Syst. 49, 337-351.

EEA (2001) Late lessons from early warnings: The precautionary principle 1896-2000, Environmental Issue Report No. 22, European Environment Agency, Copenhagen.

Elmqvist T., Folke C., Nyström M., Peterson G., Bengtsson J., Walker B., Norberg J. (2003) Response diversity, ecosystem change and resilience, Front. Ecol. Environ. 1, 488-494.
Fauvergue X., Tentelier C. (2008) Flexibilité adaptative : biologie évolutive, théorie des jeux et psychologie, in: Dedieu B., Chia E., Leclerc B., Moulin Ch., Tichit M. (Eds.), L'élevage en mouvement, Flexibilité et adaptation des exploitations d'herbivores, Ed. Quae, Paris, pp. 39-58.

Fiorelli C., Porcher J., Dedieu B. (2007) Pourquoi faire de l'élevage quand on a un autre travail ? Rencontres Recherches Ruminants 14, 389-392.

Fogel M.M., Duckstein L., Kisiel C.C. (1974) Optimum control of irrigation water application, Automatica 10, 579-586.

Folke C., Colding J., Berkes F. (2003) Synthesis: Building resilience and adaptive capacity in social-ecological systems, in: Berkes F., Colding J., Folke C. (Eds.), Navitaging social-ecological systems. Building resilience for complexity and change, Cambridge University Press, Cambridge, pp. 352-387.

Funtowicz S., Ravetz J. (1993) Science for the post-normal age, Futures $25,739-755$.

Gafsi M., Brossier J. (1997) Farm management and protection of natural resources: Analysis of adaptation process and the dependence relationships, Agr. Syst. 55, 71-97.

Giampietro M. (1997) Linking technology, natural resources, and the socio-economic structure of human society: A theoretical model, Adv. Human Ecol. 6, 75-130.

Gibon A., Sibbald A.R., Flamant J.C., Lhoste P., Revilla R., Rubino R., Sorensen J.T. (1999) Livestock farming systems research in Europe and its potential contribution for managing towards sustainability in livestock farming, Livest. Prod. Sci. 61, 121-137.

Gotsch N., Rieder P. (1990) Forecasting future developments in crop protection, Crop Prot. 9, 83-89.

Gowdy J. (2007) Avoiding self-organized extinction: Toward a coevolutionary economics of sustainability, Int. J. Sust. Dev. World Ecol. 14, 27-36.

Grumbine R.E. (1994) What is ecosystem management? Conserv. Biol. $8,27-38$.

Gueringer A., Rapey H., Houdart M., Bigot G., Josien E., Landré F. (2009) Adaptability through spatial management. A case study of livestock farms in the Massif Central, France, Outlook Agr. 38, 111-118.

Hagmann J., Chuma E. (2002) Enhancing the adaptive capacity of the resource users in natural resource management, Agr. Syst. 73, 2339.

Hart R.D., Pinchinat A.M. (1982) Integrative agricultural systems research, in: Servant J., Pinchinat A. (Eds.), Caribbean Seminar on Farming Systems Research Methodology, Pointe-à-Pitre, Guadeloupe, FWI, May 4-8, 1980, INRA-IICA Ed., pp. 555-565.

Holland J.H. (2006) Studying complex adaptive systems, J. Syst. Sci. Complex. 19, 1-8.

Holling C.S. (2001) Understanding the complexity of economic, ecological, and social systems, Ecosystems 4, 390-405.

Holling C.S., Meffe G. (1996) Command and control and the pathology of natural resource management, Conserv. Biol. 10, 328-337.

Holling C.S., Gunderson L.H., Ludwig D. (2002) In quest of a theory of adaptive change, in: Gunderson L.H., Holling C.S. (Eds.), Panarchy: Understanding Transformations in Human and Natural Systems, Island Press, Washington DC, pp. 3-22.

Hubert B., Ison R., Röling N. (2000) The 'problematique' with respect to industrialised-country agricultures, in: Cerf M., Gibbon D., Hubert B., Ison R., Jiggins J., Paine M., Proost J., Röling N. (Eds.), Cow up a tree, Learning for change in agriculture - Case studies from industrialised countries, Paris: INRA, pp. 13-29.

IAASTD (2009) Agriculture at a crossroads, Synthesis report. International Assessment of Agricultural Knowledge, Science and Technology for Development, Island Press, Washington DC. 
Ison R.L., High C., Balckmore C.P., Cerf M. (2000) Theoretical frameworks for learning-based approaches to change in industrialisedcountry agricultures, in: Cerf M., Gibbon D., Hubert B., Ison R., Jiggins J., Paine M., Proost J., Röling N. (Eds.), Cow up a tree. Knowing and learning for change in agriculture, Case studies from industrialised countries, INRA, Paris, pp. 31-53.

Ison R.L., Maiteny P.T., Carr S. (1997) Systems methodologies for sustainable natural resources research and development, Agr. Syst. 55, 257-272.

Jacobson C., Hughey K.F., Allen W.J., Rixecker S., Carter R.W. (2009) Toward more reflexive use of adaptive management, Society and Natural Resources 22, 484-495.

Jiggins J., Röling N. (1994) Systems thinking and participatory research and extension skills: Can these be taught in the classroom? Occasional Papers in Rural Extension, No. 10, Dept. of Rural Extension Studies, University of Guelph.

Kahneman D. (2003) Maps of bounded rationality: Psychology for behavioural economics, Am. Econ. Rev. 93, 1449-1475.

Lee K.N. (1999) Appraising adaptive management, Conservation Ecology 3, 3, URL: http://www.ecologyandsociety.org/vol3/iss2/ art3/.

Lemery B., Ingrand S., Dedieu B., Degrange B. (2005) Agir en situation d'incertitude : Le cas des éleveurs bovins allaitants, Econ. Rurale 288, 57-69.

Lev L., Campbell D. (1987) The temporal dimension in Farming Systems Research: The importance of maintaining flexibility under conditions of uncertainty, J. Rural Studies 3, 123-132.

Levin S.A. (1998) Ecosystems and the biosphere as complex adaptive systems, Ecosystems 1, 431-436.

Levrouw F., Morales H., Arbeletche P., Malaquin I., Tourrand J.F., Dedieu B. (2007) Les élevages uruguayens, le long terme et les incertitudes : une diversité de stratégies pour se maintenir dans la production, Rencontres Recherches Ruminants 14, 413-416.

Long N. (1984) Creating space for change. A perspective on the sociology of development, Sociologia Ruralis 24, 168-184.

Lopez-Ridaura S., van Keulen H., van Ittersum M., Leffelaar P.A. (2005) Multiscale methodological framework to derive criteria and indicators for sustainability evaluation of peasant natural resource management systems, Environ. Dev. Sustain. 7, 51-69.

Macé K., Morlon P., Munier-Jolain N., Quéré L. (2007) Time scales as a factor in decision-making by French farmers on weed management in annual crops, Agr. Syst. 93, 115-142.

Madelrieux S., Dedieu B. (2008) Qualification and assessment of work organisation in livestock farms, Animal 2, 435-447.

Magne M.-A., Cerf M. (2009) How information becomes a resource for action in an uncertain and complex world, Outlook Agr. 38, 157165.

Manson S.M. (2001) Simplifying complexity: a review of complexity theory, Geoforum 32, 405-414.

Mayumi K., Giampietro M. (2001) The epistemological challenge of modelling sustainability: Risk, uncertainty and ignorance, Paper prepared for FRONTIERS 1, held 4-7 July 2001 at New Hall, Cambridge, UK.

Millennium Ecosystem Assessment (2005) Ecosystems and Human Wellbeing: Synthesis, Island Press, Washington, DC.

Meyer A.D., Gaba V., Colwell K.A. (2005) Organizing far from equilibrium: Nonlinear changes in organizational fields, Organization Sci. $16,456-473$.

Norman D.W. (2002) The farming systems approach: A historical perspective, Presentation held at the 17th Symposium of the International Farming Systems Association in Lake Buena Vista, Florida, USA, 17-20 Nov. 2002.
Norman D.W., Malton P.J. (2000) Agricultural systems research and technical change, in: Colin J.-P., Crawford E.W. (Eds.), Research on Agricultural Systems. Accomplishments, Perspectives and Issues, Nova Science Publishers, pp. 17-47.

Norton G.A. (1976) Analysis of decision making in crop protection, Agro-Ecosystems 3, 27-44.

OECD (2009) The role of agriculture and farm household diversification in the rural economy: Evidence and initial policy implications, Document TAD/CA/APM/WP(2009)1/FINAL, Organisation for Economic Co-operation and Development, Paris.

Okey B.W. (1996) Systems approaches and properties, and agroecosystem health, J. Environ. Manage. 48, 187-199.

Olsson P., Folke C. (2001) Local ecological knowledge and institutional dynamics for ecosystem management: A study of Lake Racken Watershed, Sweden, Ecosystems 4, 85-104.

Ondersteijn C.J., Giesen G.W., Huirne R.B. (2006) Perceived environmental uncertainty in Dutch dairy farming: The effect of external farm context on strategic choice, Agr. Syst. 88, 205-226.

Østergård H., Finckh M., Fontaine L., Goldringer I., Hoad S., Kristensen K., Lammerts van Bueren E., Mascher F., Munk L., Wolfe M. (2009) Time for a shift in crop production: Embracing complexity through diversity at all levels, J. Sci. Food Agr. 89, 1439-1445.

Osty P.L. (1978) L'exploitation agricole vue comme un système, Bulletin Technique d'Information, Paris : Ministère de l'Agriculture.

Park J., Seaton R.A. (1996) Integrative research and sustainable agriculture, Agr. Syst. 50, 81-100.

Penrose E. (1997) The theory of the growth of the firm, in: Foss N. (Ed.), Resources, firms and strategies. A reader in the resource-based perspective, Oxford University Press, Oxford, pp. 27-39.

Petit M. (1978) The farm household complex as an adaptive system, Proceedings of the 4 Forschungscolloquium des Lehrstuhls für Wirtschaftslehre des Landbaus, Arbeitsbericht 78/1, Institut für Landwirtschaftliche Betriebs- und Arbeitslehre, University of Kiel, pp. 57-70.

Petit M. (1981) Théorie de la décision et comportement adaptatif des agriculteurs, Formation des agriculteurs et apprentissage de la decision, Dijon, ENSSAA, INPSA, INRA, INRAP.

Puilliez L., Martin O., Tichit M., Sauvant D. (2008) Simple representation of physiological regulations in a model of lactating female: Application to the dairy goat, Animal 2, 235-246.

Rammel C. (2003) Sustainable development and innovations: Lessons from the Red Queen, Int. J. Sust. Dev. 6, 395-416.

Rammel C., van den Bergh J. (2003) Evolutionary policies for sustainable development: adaptive flexibility and risk minimising, Ecol. Econ. 47, 121-133.

Rammel C., Stagl S., Wilfing H. (2007) Managing complex adaptive systems - A co-evolutionary perspective on natural resource management, Ecol. Econ. 63, 9-21.

Rathe K., Witt U. (2001) The nature of the firm - Static versus developmental interpretations, J. Manage. Governance 5, 331-351.

Reix R. (1979) La flexibilité de l'entreprise, Éditions Cujas, Paris.

Sánchez E., Sifres A., Casañas F., Nuez F. (2008) The endangered future of organoleptically prestigious European landraces: Ganxet bean (Phaseolus vulgaris L.) as an example of a crop originating in the Americas, Genet. Resour. Crop Ev. 55, 45-52.

Scoones I., Thompson J. (1994) Beyond farmer first: rural people's knowledge, agricultural research and extension practice, London: Intermediate Technology Publications. 
Seath G.W., Webby R.W. (2000) The results and success factors of a farm monitoring and study group approach to collective learning in New Zealand, in: Cerf M., Gibbon D., Hubert B., Ison R., Jiggins J., Paine M., Proost J., Röling N. (Eds.), Cow up a tree. Knowing and learning for change in agriculture, Case studies from industrialised countries, INRA, Paris, pp. 111-119.

Simon H.A. (1986) Rationality in Psychology and Economics, J. Business 59, S209-S224.

Slaughter D.C., Giles D.K., Downey D. (2008) Autonomous robotic weed control systems: A review, Comput. Electron. Agr. 61, 63-78.

Smit B., Wandel J. (2006) Adaptation, adaptive capacity and vulnerability, Global Environ. Chang. 16, 282-292.

Smit H.T., Trigeorgis L. (2006) Strategic planning: Valuing and managing portfolios of real options, R\&D Management 36, 403-419.

Stewart P. (2001) Complexity theories, social theory and the question of social complexity, Philos. Soc. Sci. 31, 323-360.

Sumberg J., Okali C., Reece D. (2003) Agricultural research in the face of diversity, local knowledge and the participation imperative: Theoretical considerations, Agr. Syst. 76, 739-753.

Tarondeau J.-C. (1999) Approches et formes de flexibilité, Revue Française de Gestion 123, 66-71.

Teece D.J. (2007) Explicating dynamic capabilities: The nature and microfoundations of (sutainable) enterprise performance, Strategic Manage. J. 28, 1319-1350.

Tichit M., Ingrand S., Moulin C.H., Cournut S., Lasseur J., Dedieu B. (2004) Analyser la diversité des trajectoires productives des femelles reproductrices : intérêts pour modéliser le fonctionnement du troupeau en élevage allaitant, INRA Productions Animales 17, 123-132.

Tilman D., Cassman K.G., Matson P.A, Naylor R., Polasky S. (2002) Agricultural sustainability and intensive production practices, Nature 418, 671-677.
Tsai Y.J., Mishoe J.W., Jones J.W. (1987) Optimizing multiple cropping systems: Simulation studies, Agr. Syst. 25, 165-176.

Trigeorgis L. (2005) Making use of real options simple: An overview and applications in flexible/modular decision making, Eng. Econom. $50,25-53$.

Urry J. (2005) The complexities of the global, Theory, Culture and Society 22, 235-254.

van den Bergh J.C., Ferrer-i-Carbonell A., Munda G. (2000) Alternative models of individual behaviour and implications for environmental policy, Ecol. Econ. 32, 43-61.

van den Bergh J.C. (2007) Evolutionary thinking in environmental economics, J. Evolution. Econ. 17, 521-549.

Walker B., Gunderson L., Kinzig A., Folke C., Carpenter S., Schultz L. (2006) A handful of heuristics and some propositions for understanding resilience in social-ecological systems, Ecology and Society 11, 13, http://www.ecologyandsociety.org/vol11/iss1/ $\operatorname{art} 13 /$.

Walsh J.P., Meyer A.D., Schoonhoven C. (2006) A future for organization theory: Living in and living with changing organizations, Organization Sci. 17, 657-671.

Westley F. (2002) The devil in the dynamics: Adaptive management on the front lines, in: Gunderson L.H., Holling C.S. (Eds.), Panarchy, Understanding Transformations in Human and Natural Systems, Island Press, Washington DC, pp. 333-360.

Wilson G.A. (2008) From 'weak' to 'strong' multifunctionality: Conceptualising farm-level multifunctional transitional pathways, J. Rural Studies 24, 367-383.

Wolfe M.S., Baresel J.P., Desclaux D., Goldringer I., Hoad S., Kovacs G., Löschenberger F., Miedaner T., Østergård H., Lammerts van Bueren E.T. (2008) Developments in breeding cereals for organic agriculture, Euphytica 163, 323-346. 